\title{
Dating the Morasko meteorite fall by natural thermoluminescence of the fusion crust
}

\author{
Stanisław Fedorowicz ${ }^{1} \&$ Wojciech T.J. Stankowski ${ }^{*}$ \\ ${ }^{1}$ University of Gdańsk, Institute of Geography, Department of Geomorphology and Quaternary Geology, \\ ul. Bażyńskiego 4, 80-950 Gdańsk, Poland \\ ${ }^{2}$ Institute of Geology, Adam Mickiewicz University, ul. Maków Polnych 16, 61-606 Poznań, Poland \\ *corresponding author, e-mail: stawgeo@amu.edu.pl
}

\begin{abstract}
The date of fall of the Morasko iron meteorite was determined by means of thermoluminescence measurements of the fusion crust and related local materials. Three small pieces, commonly referred to as 'shrapnel', were used. The results obtained are 4.5-5.0 ka, which is in good agreement with previous estimates of 4-6 ka on the basis of radiometric, dosimetric and palynological methods.
\end{abstract}

Keywords: iron meteorite, terrestrial age, dosimetry, Poland

\section{Introduction}

The high surface temperature of a meteor that passes through the Earth's atmosphere produces varied superficial ablative niches and a thin fusion/ melt zone, or film. In stony meteorites real luminescence resetting is affected, while in metallic ones only the status of the matter is changed. When iron meteorites fall onto mineral substrates, there is zonal variety of thermal effects around the meteorite. That lead to the formation the extremely thin fusion layer and also the spatially limited "encapsulation" of the fused/molten matter of the encountered meteorite mineral grains. A very thin "semi-fused unit" /"semi-melt" is formed, enabling luminescent dating on account of the presence of mineral grains. The outer, different in size sinter layer is created. Weathering processes occur later and lead to some changes in these two crusts. Most small meteorites recovered (usually "shrapnel" of larger-sized extraterrestrial bodies) possess two types of crusts: (1) a fusion-weathering crust, covering the external surface of the initial meteorite interior, and (2) a sin- ter-weathering crust, consisting of sediments or rocks onto which the meteorite fell. In material thus defined, obtained from small meteorites collected in the northeasternmost part of the Morasko Meteorite Nature Reserve, dating was performed by thermoluminescence (TL). This is the main scope of research into the Morasko meteorite shower, leading to addition of new data that are complementary to previous studies. The dating of the meteoritic material was verified by comparison with data from mineral deposits in the immediate vicinity of the meteorite. Additionally, TL data of sinter-weathering crust that covered great meteorites obtained earlier were included as comparative data. The age of $\sim 5,000$ years BP thus obtained confirms previous similar findings with regard to the time of the main (primary) Morasko impact. It should be added that during the last 5,000 years another, younger $(\sim 2,000$ $\mathrm{BP})$ meteorite fall appears probable in the Morasko area (see Stankowski, 2009). However, possibility that the second meteorite impact could occur in the some place on the Earth, seems to be almost exceptional. 
Studies of the Morasko meteorite shower (Morasko Meteorite Nature Reserve, Poland, and its surroundings; see Fig. 1) have yielded a significant amount of data on the mineralogy, geochemistry and timing of this cosmic event, as well as on geoenvironmental issues (Hurnik, 1976; Stankowski, 2009, 2011; Stankowski et al., 2007; Stankowski \& Bluszcz, 2012; Dworzyńska \& Muszyński, 2010; Muszyński et al., 2012). The fundamental piece of evidence for this impact (countering views that the Morasko meteorites had been brought by an ice sheet/ice sheets, as erratics), was the 2011 discovery of a meteorite lump of $\sim 34 \mathrm{~kg}$ at a depth of $\sim 160$ $\mathrm{cm}$. It was found in glaciotectonically disturbed Neogene sediments of the "Poznań Series", which are present just beneath the present-day surface (data on this find: Meteorite Men, episode 302 `Morasko
Poland', Science Channel, 2011). The object penetrated the thin, superficial layer of Quaternary sediments, which explains the presence of fragments of granitic material found in the leading part of the meteorite. The relevant lithological characteristics of the impact site are documented in the form of mineralogical data (see Karwowski et al., 2011).

Amongst the smaller meteorites found at Morasko, the 970-g specimen, has the best-developed crust with two units (well seen under petrographic microscope and supported by SEM/ESD analyses): fusion/melt/'semi-melt' layer and sinter layer (see Figs 2, 3).

A similar structure of meteorite crust development was recognised and TL dating carried out on the $62-\mathrm{g}, 70 \mathrm{-g}$ and $1201 \mathrm{-g}$ specimens. In the case of the 70-g meteorite "shrapnel", the surrounding ma-
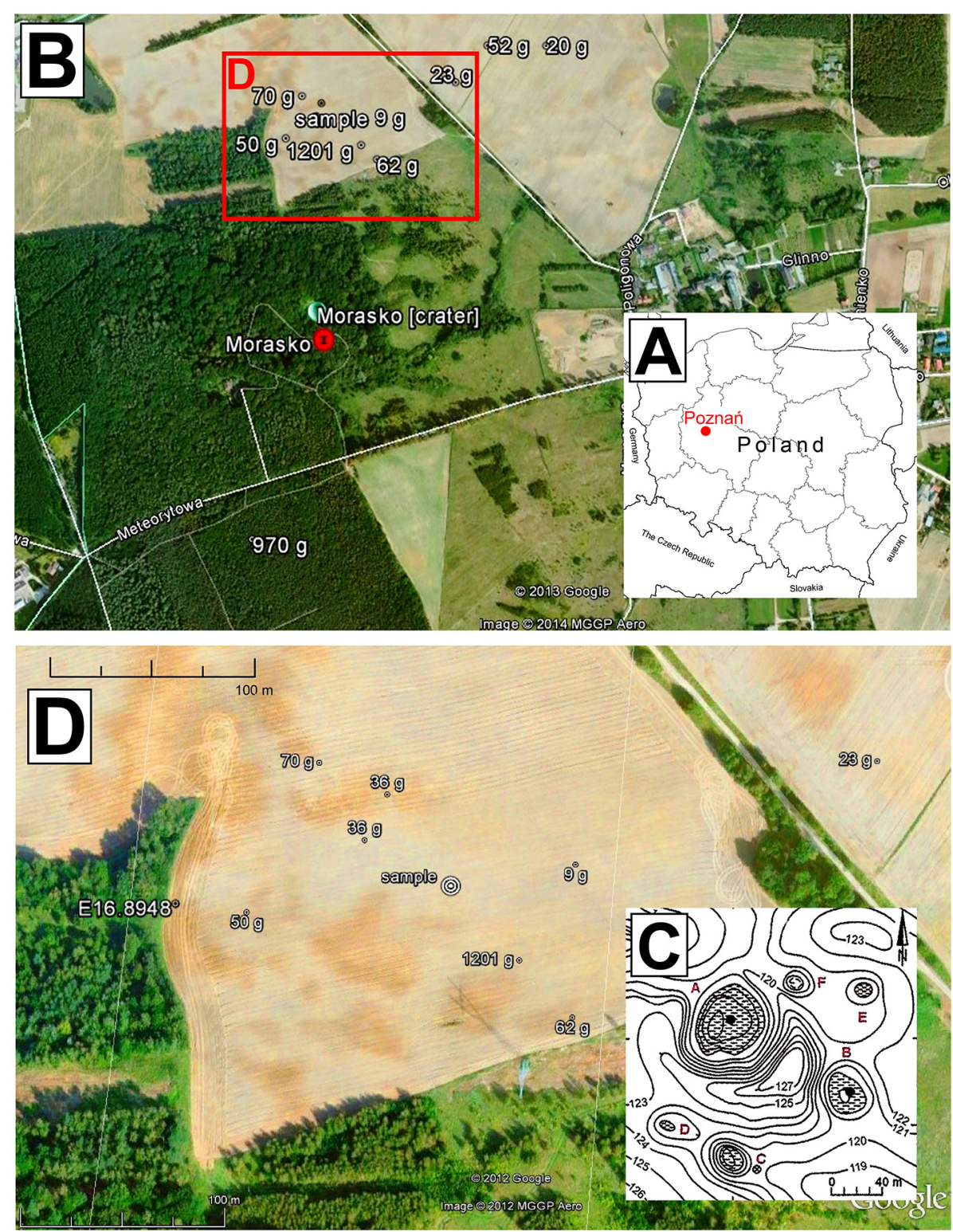

Fig. 1.A - Location of the site studied; B - Position of meteorite finds (about $500 \mathrm{~m}$ north of the largest crater); the signature 'sample' indicates the location of the $\sim 70$ g meteorite, found at a depth of $\sim 30 \mathrm{~cm}$ (co-ordinates $\mathrm{N} 52^{\circ} 29.60^{\prime}, \mathrm{E}$ $16^{\circ} 53.84^{\prime}$ ) from which the sample for luminescence dating was obtained, from a thin fusion crust. The newest meteorite, of $970 \mathrm{~g}$, examined was found about $400 \mathrm{~m}$ to the south-southwest of the largest crater (co-ordinates N 52²9.42', E $\left.16^{\circ} 53.80^{\prime}\right)$; C - Topography of the Morasko Meteorite Reserve, A-F - meteorite craters, a $7.5-\mathrm{kg}$ meteorite was found near crater C; a $164-\mathrm{kg}$ meteorite was recovered from the top of the hill between craters A, B and $C$ in 2006; a 261-kg meteorite was collected from $\sim 300 \mathrm{~m}$ to the southwest of the top of the hill in 2012; D - Enlarged area of meteorite finds. 
Fig. 2. The $970-\mathrm{g}$ meteorite found in 2014 by M. Szyszko, with fusion/molten and sintered coating. 1 - iron-nickel alloy; 2 - remainder of fusion/molten area; $2 \mathrm{a}$ - zone and packs of interaction - fusion/molten matter of meteorite ('matrix') and material of the place of impact (grains) = 'semi-fusion'/'semi-molten' layer; 3 - sinter/sintered layer.
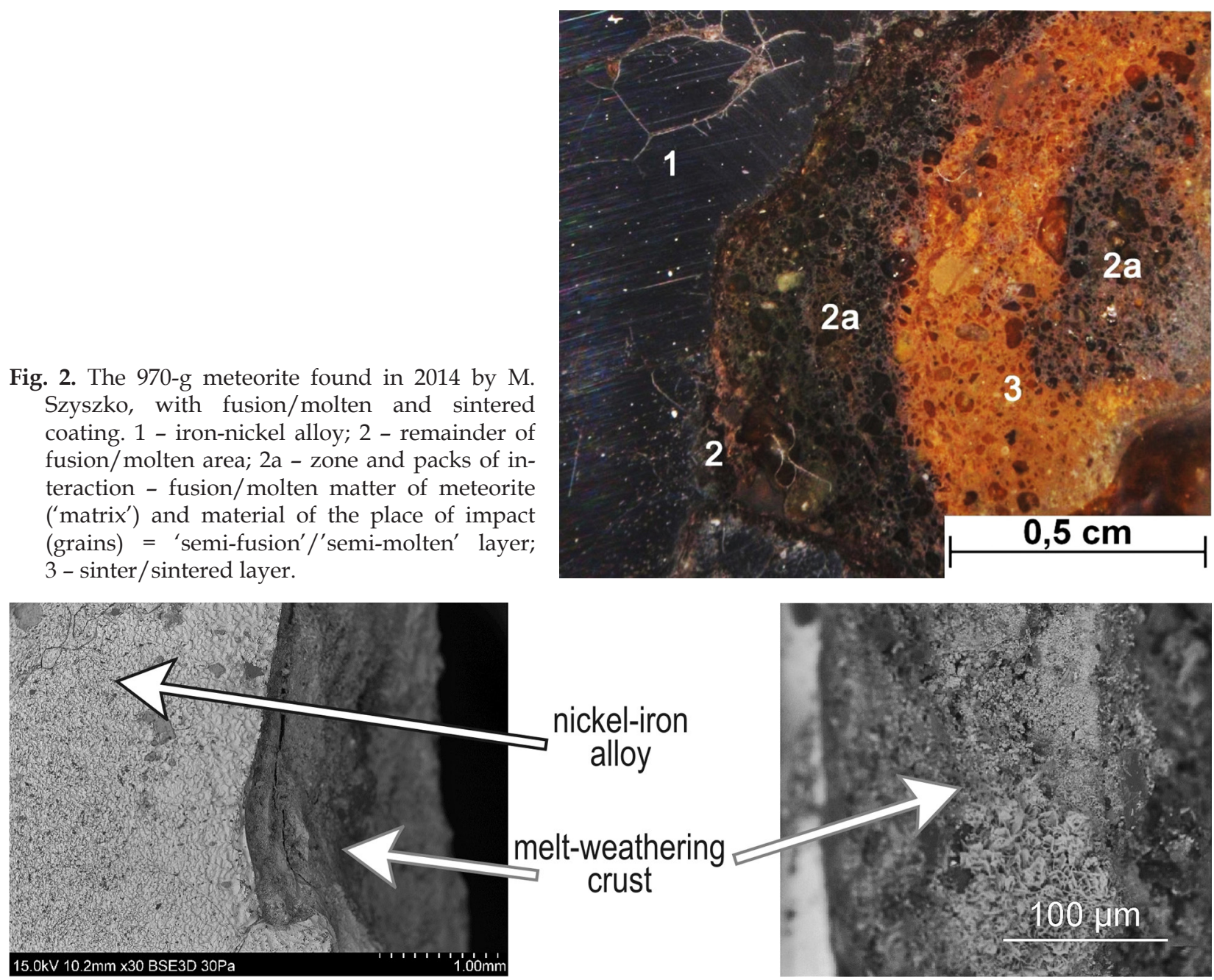

Fig. 3. Part of the interior and true melt/molten crust and 'semi-molten' part with mineral grains of the 62-g meteorite. The chemical analyses (mean semi-quantitative wt. percentage data in oxides for 26 measurements) run for both parts: a) nickel-iron alloy: $\mathrm{Fe}_{3} \mathrm{O}_{4}=92.6 ; \mathrm{NiO}=6.8$; others = trace only, b) melt crust/'matrix': $\mathrm{Fe}_{3} \mathrm{O}_{4}=81.3 ; \mathrm{NiO}=$ $4.5 ; \mathrm{MgO}=2.7 ; \mathrm{SiO}_{2}=2.4 ; \mathrm{Al}_{2} \mathrm{O}_{3}=1.8$; others $\sim 7$, grains: $\mathrm{Fe}_{3} \mathrm{O}_{4}=12.6 ; \mathrm{NiO}=$ trace; $\mathrm{SiO}_{2}=75.4 ; \mathrm{Al}_{2} \mathrm{O}_{3}=7.8 ;$ others $\sim 4$.

Fig. 4. Grains analysed from sediments surrounding the $70-\mathrm{g}$ meteorite; exemplary group of grains; the white colour are iron ones.

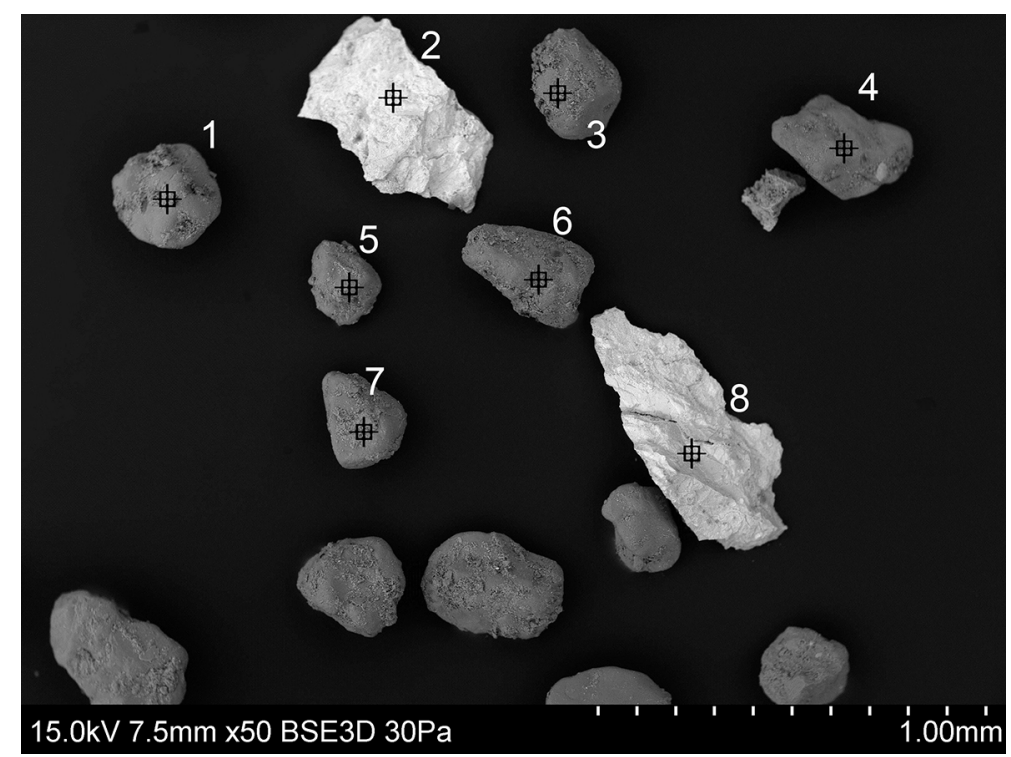


Table 1. Chemical composition of grains from above (depth: $25 \mathrm{~cm}$ ) and below (depth: $30 \mathrm{~cm}$ ) the 70-g meteorite - mean wt. percentage data in oxides. Some grains have a composition that is characteristic of nickel-iron meteorites (nos. 2 and 8 in Fig. 4).

\begin{tabular}{|c|c|c|c|c|c|c|}
\hline Grains/measurements & $\mathrm{Al}_{2} \mathrm{O}_{3}$ & $\mathrm{SiO}_{2}$ & $\mathrm{TiO}_{2}$ & $\mathrm{Fe}_{3} \mathrm{O}_{4}$ & $\mathrm{NiO}$ & $\mathrm{Cu}_{2} \mathrm{O}$ \\
\hline ironic (4 measur.) & $\begin{array}{c}0.8 \\
(0.5-0.9)\end{array}$ & $\begin{array}{c}1.6 \\
(1.0-2.4)\end{array}$ & trace & $\begin{array}{c}90.1 \\
(86.6-91.2\end{array}$ & $\begin{array}{c}6.6 \\
(4.9-7.1)\end{array}$ & \\
\hline others: a (5 measur.) & $\begin{array}{c}4.5 \\
(2.7-5.6)\end{array}$ & $\begin{array}{c}15.8 \\
(7.0-20.5)\end{array}$ & trace & $\begin{array}{c}78.6 \\
(69.1-87.5\end{array}$ & $\begin{array}{c}0.6 \\
(0.1-1.5)\end{array}$ & \\
\hline b (7 measur.) & $\begin{array}{c}8.2 \\
(1.4-18.2)\end{array}$ & $\begin{array}{c}75.4 \\
(52.5-93.2)\end{array}$ & 0.3 & $\begin{array}{c}15.2 \\
(2.4-25.6)\end{array}$ & $\begin{array}{c}0.2 \\
(0.0-1.5)\end{array}$ & \\
\hline c (9 measur.) & $\begin{array}{c}81.2 \\
(71.0-89.6)\end{array}$ & $\begin{array}{c}1.2 \\
(0.0-10.5)\end{array}$ & & $\begin{array}{c}5.1 \\
(0.0-14.6)\end{array}$ & & $\begin{array}{c}12.1 \\
(0.0-15.6)\end{array}$ \\
\hline
\end{tabular}

terial was analysed using SEM and ESD techniques, and TL dating performed (see Fig. 4; Table 1).

The chemical composition of crusts covering the metallic Morasko meteorites reveals opportunities for TL dating of the time of zeroing luminescence. These data seem to be real time indicators of the impact event.

\section{Luminescence (TL) dating, procedures and sample preparation}

In order to determine the luminescence age of the sediment under study, it is important to determine the equivalent dose $\left(d_{e}\right)$ and the annual dose $\left(d_{r}\right)$. The former can be determined with a luminescence reader, while the latter dose (dose rate) can be assessed by different methods. Usually, it is determined by gamma spectroscopy and ormass spectrometry (ICP-MS).

Before starting luminescence measurements, the activity of natural radionuclides $\left({ }^{238} \mathrm{U}\right.$ and ${ }^{232} \mathrm{Th}$ series and ${ }^{40} \mathrm{~K}$ ) in the material to be TL dated was measured in order to determine the annual dose. Simultaneously, an artificial isotope ${ }^{137} \mathrm{Cs}$ in samples was calculated. This was done with a semi-conductor gamma spectrometer equipped with a coaxialHPGe detector with a relative efficiency of 35 per cent at energy $1330 \mathrm{keV}$ manufactured Canberra. Before measuring radioactivity, the samples were dried and placed in measurement containers for about four weeks in order to achieve equilibrium between ${ }^{226} \mathrm{Ra}$ and its daughter ${ }^{222} \mathrm{Rn}$. The counting time was typically about two days.

The standards, RGU-1, RGTh-1 and RGK-1 (provided by the IAEA), were used to calibrate the germanium detector in case of analytical activities of ${ }^{238} \mathrm{U}$ and ${ }^{232} \mathrm{Th}$ series and ${ }^{40} \mathrm{~K}$ in samples; for calculation of activity of ${ }^{137} \mathrm{Cs}$ in a sample the standard Soil-375, also provided by IAEA, was used. The values thus obtained were subsequently converted to a dose rate (Adamiec \& Aitken, 1998).

For the sequence of ${ }^{238} \mathrm{U}$, the activity calculations were performed on the basis of the following lines of gamma radiation: $295.1 \mathrm{keV}^{214} \mathrm{~Pb}, 352.0 \mathrm{keV}{ }^{214} \mathrm{~Pb}$, $609.3 \mathrm{keV}{ }^{214} \mathrm{Bi}$ and $1120.3 \mathrm{keV}{ }^{214} \mathrm{Bi}$, whereas analyses for the sequence of ${ }^{232} \mathrm{Th}$ were based on the lines $583.0 \mathrm{keV}{ }^{208} \mathrm{Tl}, 911.2 \mathrm{keV}{ }^{228} \mathrm{Ac}$ and $2614.4 \mathrm{keV}{ }^{208} \mathrm{Tl}$ . For ${ }^{40} \mathrm{~K}$, the computations were performed on the basis of the energy line of $1460.8 \mathrm{keV}$ and for ${ }^{137} \mathrm{Cs}$ the calculation was done as based on the line 661.7 $\mathrm{keV} .{ }^{137} \mathrm{Cs}$ is an artificial isotope which is liberated into the atmosphere as a result of nuclear weapon tests and the Chernobyl nuclear disaster. Following deposition on the Earth's surface this is rapidly and intensey absorbed by soil particles. The maximum fall out was in the mid-1960s and, in the case of Polish territory, high deposition occurred in 1986 following the Chernobyl accident.

In addition to data on the radioactivity of a sample, it is also necessary to determine the contribution of cosmic rays in the annual radiation dose. The space component of the annual dose was determined by using the equation proposed by Prescott\& Hutton (1994). The resultant annual dose (Adamiec \& Aitken, 1998) also includes a correction for humidity, as described by Aitken (1985). In the present study, a humidity of 10 per cent was assumed. For further calculations, a mean value of $10 \pm 5$ per cent was used. Results of the measurement of the activity and dose rate for the Morasko samples are listed in Table 2.

The TL dating was done on two types of material: three samples of the meteorite crusts and two samples of the sandy material surrounding the 70-g meteorite. To do so, samples were subjected to different preparation methods for the measurement of the equivalent dose in luminescence dating. The measurement of the equivalent dose for both materials was performed by using the standard multiplealiquot regenerative thermoluminescence method. The material from the melt crust of the meteorite 
Table 2. Results of measurements of radioactivity and calculated annual and equivalent doses and TL age of samples from melt-crusts of the 70-g, 1201-g and 62-g meteorite and the comparative meteorites, as well as material surrounding the 70-g meteorite from Morasko (dose rate determined by G. Poręba, Institute of Physics, Silesian Technical University).

\begin{tabular}{|c|c|c|c|c|c|c|c|c|}
\hline \multicolumn{2}{|c|}{ Sample } & No lab. & $\begin{array}{c}{ }^{40} \mathrm{~K} \\
{[\mathrm{~Bq} / \mathrm{kg}]}\end{array}$ & $\begin{array}{c}{ }^{238} \mathrm{U} \\
{[\mathrm{Bq} / \mathrm{kg}]}\end{array}$ & $\begin{array}{c}{ }^{232} \mathrm{Th} \\
{[\mathrm{Bq} / \mathrm{kg}]}\end{array}$ & $\begin{array}{l}\text { Dose rate } d_{r} \\
{[G y / k a]}\end{array}$ & $\begin{array}{c}\text { Equivalent } \\
\text { dose } d_{e} \\
{[G y]}\end{array}$ & $\begin{array}{c}\text { TL age } \\
\text { [ka] }\end{array}$ \\
\hline $\begin{array}{l}\text { Fusion/ } \\
\text { melt-crusts } \\
\text { of meteor- } \\
\text { ites }\end{array}$ & $\begin{array}{r}70 \mathrm{~g} \\
1201 \mathrm{~g} \\
62 \mathrm{~g}\end{array}$ & $\begin{array}{l}6603 \\
6682 \\
6683\end{array}$ & $\begin{array}{c}109.6 \pm 8.9 \\
126.2 \pm 10.5 \\
92.7 \pm 11.2\end{array}$ & $\begin{array}{l}10.3 \pm 0.8 \\
20.7 \pm 1.3 \\
40.5 \pm 2.4\end{array}$ & $\begin{array}{l}7.9 \pm 0.6 \\
8.6 \pm 1.7 \\
8.0 \pm 1.8\end{array}$ & $\begin{array}{l}0.75 \pm 0.08 \\
0.91 \pm 0.09 \\
1.17 \pm 0.10\end{array}$ & $\begin{array}{l}3.5 \pm 0.4 \\
4.5 \pm 0.6 \\
5.4 \pm 1.0\end{array}$ & $\begin{array}{l}4.7 \pm 0.7 \\
4.9 \pm 0.9 \\
4.6 \pm 0.8\end{array}$ \\
\hline $\begin{array}{l}\text { Material } \\
\text { surround- } \\
\text { ing } 70-g \\
\text { meteorite }\end{array}$ & $\begin{array}{c}\text { top sample } \\
\text { (depth } \sim 25 \mathrm{~cm}) \\
\text { basal sample } \\
(\text { depth } \sim 30 \mathrm{~cm})\end{array}$ & 6604 & $404.0 \pm 10.6$ & $16.1 \pm 1.2$ & $17.1 \pm 1.2$ & $1.85 \pm 0.10$ & $10.0 \pm 1.0$ & $5.4 \pm 0.8$ \\
\hline
\end{tabular}

was crushed in a hand mortar. After grinding, the particle size was below $40 \mu \mathrm{m}$. This material was rinsed in distilled water and dried. After this treatment the equivalent dose $\left(d_{e}\right)$ was measured with the multiple-aliquot regenerative technique (Wintle \& Prószyńska, 1983). The sandy material from the surrounding area underwent a slightly different pre-treatment and luminescence procedure. In this case the equivalent dose $\left(d_{e}\right)$ was determined for quartz grains in the size range of $80-100 \mu \mathrm{m}$; the multiple-aliquot regenerative technique was applied here as well. In this case, the separated grains were treated with $10 \% \mathrm{HCl}$ for two hours, then for the same time with $2 \% \mathrm{NaOH}$ and subsequently with $40 \%$ HF for 45 minutes (Bluszcz, 2000; Fedorowicz, 2006). After each of these steps, the samples were rinsed several times with distilled water.

After the initial preparation, both material types were divided into two parts. The first one, left in its original state, was used to measure natural thermoluminescence (NTL). The remaining, larger part was optically bleached for up to 12 hours by exposure to UV light simulating sunlight. For this purpose, an Osram Ultra-Vitalux $300 \mathrm{~W}$ lamp was used. The bleached material was divided into five equal portions. The first one was used to measure the residual thermoluminescence, while the four remaining parts were irradiated with cobalt that would regenerate the previously acquired energy. The bleached parts were irradiated with cobalt radiation of 10, 20, 30 and $50 \mathrm{~Gy}$, respectively. In addition, doses of 10 and 20 Gy were used to irradiate the previously non-bleached portions, of which the material was used for measuring natural thermoluminescence.

The equivalent dose $(D e)$ was measured with a reader/analyser, model RA'94 equipped with a filter BG-28 (360-510 nm). Samples of $5 \mathrm{mg}$ were heated in an argon atmosphere up to $400^{\circ} \mathrm{C}$ with a heating rate of $8^{\circ} / \mathrm{s}$.

TL curves of meteorite samples usually have two maxima, the first of about $240^{\circ} \mathrm{C}$, the second about $320^{\circ} \mathrm{C}$. The method of bleaching was experimentally examined. The temperature bleaching caused a decrease in the height of the peaks mentioned to the level of 2-3 per cent of maximum NTL, whereas optical bleaching caused a decrease to 3-4 per cent. In further research the optical bleaching and TL glow curve were used in the performed analysis. The sensitivity of the test samples was checked and a plateau test was performed in the temperature range of 180 to $280^{\circ} \mathrm{C}$. The plateau for this temperature range was linear. An example of TL glow curves is shown in Fig. 5.

\section{Dating results}

Instrumental analysis was carried out for the fusion/melt-crust material of the $\sim 70$-meteorite and two comparative samples weighing $\sim 62 \mathrm{~g}$ and 1201 g (Table 2; Fig. 5). Material surrounding the 70-g meteorite was also analysed (see Table 2; Fig. 6); it shows a slightly smaller resetting.

The TL dates of the fusion/melt-weathering crusts turned out to be very similar. However, in terms of elements responsible for the annual doses and the annual dose $\left(\mathrm{d}_{\mathrm{r}}\right)$ itself, the meteorite matter shows striking differences. Concentrations of uranium, thorium and potassium differ in the meteorite material. The estimated radioactivity in the meteorite does not include the contribution of cosmogonic nuclide. This may indicate that the samples analysed do not come from a single meteorite (but perhaps from a shower of meteorites, or possibly not from a single event(?), if it really existed), or that the Morasko meteor, exploding in the air, was charac- 

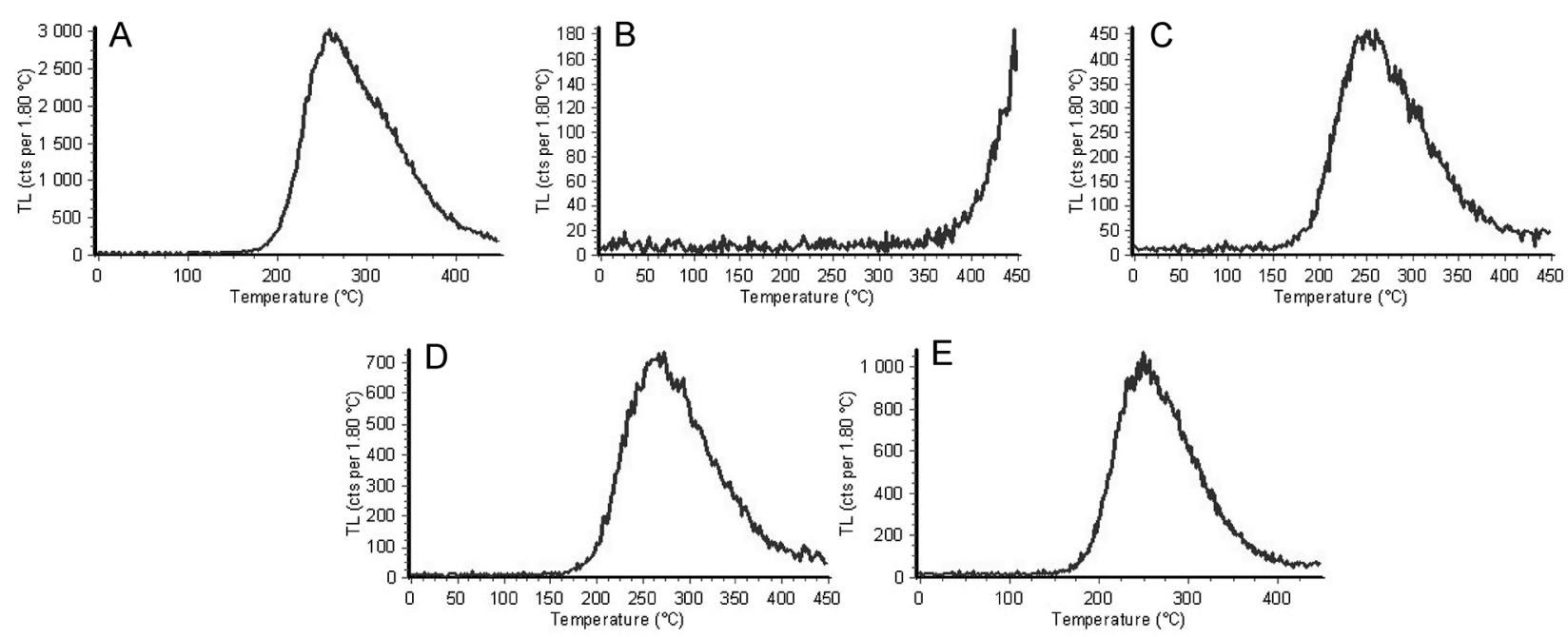

Fig. 5. Example of a TL glow curve measured for sample UG-6683. The material portions of $15 \mathrm{mg}$ were heated at a speed of $3^{\circ} \mathrm{C} / \mathrm{s}$ in RISO TL/OSL READER MODEL DA-20 with a U340 200-350 nm filter. The measurements of single portions were done by K. Standzikowski at the Laboratory of Geoecology and Palaeography Department of the Maria Curie-Skłodowska University at Lublin.

A - Intensity natural TL (NTL); B - intensity residual TL (RTL) - preheated for 30 min at $400^{\circ}$ C; C - intensity RTL+0,9 Gy (beta irradiations were performed in the range $0.9 \mathrm{~Gy}$ ); D - intensity RTL+1.3 Gy (beta irradiations were performed in the range 1.3 Gy); E - intensity RTL+1.9 Gy (beta irradiations were performed in the range 1.9 Gy).

terised by a diverse structure. It is confirmed by the outcome of mineralogical studies of the meteorite found in 2011 (Karwowski et al., 2011).

The resetting age of the studied fusion/ melt-weathering crusts, ranging between 4.6 and $4.9 \mathrm{ka}$, is burdened with a considerable measurement error for the interval from $\sim 14$ up to even $\sim 19$ per cent. However, the dates, oscillating around $\sim 5$ $\mathrm{ka}$, are within results previously obtained with regard to the time of the Morasko impact. This holds for (1) the luminescent age of the sinter-weathering crusts, (2) the reset time of the mineral material from the crater floors, and (3) the radiocarbon dating of organic matter filling the craters (Stankowski, 2001, 2009, 2011; Stankowski \& Bluszcz, 2012; Stankowski et al., 2007; Stankowski \& Muszyński, 2008).

The TL dates for the two samples of material from depths of $\sim 25 \mathrm{~cm}$ and $\sim 30 \mathrm{~cm}$, just above and below the meteorite samples ( $\sim 70 \mathrm{~g})$ seem to be slightly younger than TL dates for the meteorite sample, but the statistical test does not confirm this.
The sediment samples have similar concentrations of uranium, thorium and potassium. The calculated annual doses (Dr) are almost identical, which confirms the homogeneity of the material. Thus it can be deduced that the analysed grains of both samples underwent the same resetting of energy stored in them or an identical decrease in their energy when they came into contact with the hot meteorite. The TL age of about $5.5 \mathrm{ka}$ of both samples, slightly older than the dates of the melt-weathering crusts, might indicate that the resetting of the luminescence signal in those grains was not completed during the impact. It must be noted, however, that the basic dates of both types of material fall within the limits of measurement errors (see Table 2; Fig. 6 ), so that they should statistically be considered as having occurred simultaneously.

The size of energy accumulated in the grains is identified with the value of equivalent dose (Table 2). This value is small, between 3.5 and $5.4 \mathrm{~Gy}$. It was acquired within 4.6 to $4.9 \mathrm{ka}$. It is unclear if

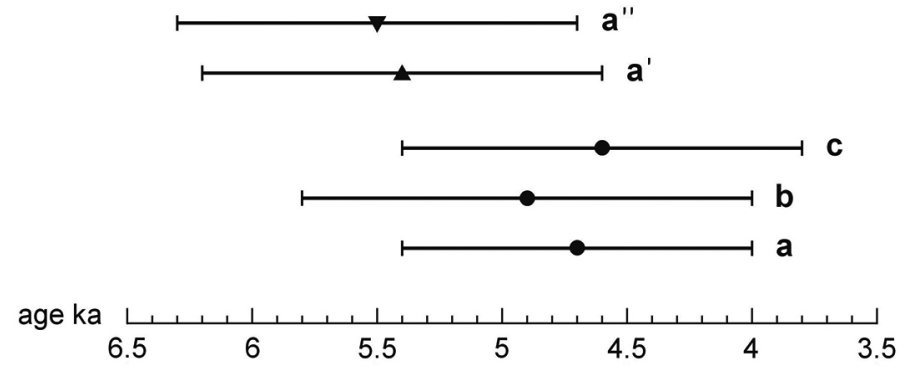

Fig. 6. Plot of TL dates of the fusion/melt-weathering crusts of the meteorites studied and the mineral deposits above and below the 70-g meteorite.

a -70-g meteorite; b -1201-g meteorite; c - 62-g meteorite. Sediment samples from near the 70-g meteorite: a' - sample from a depth of $\sim 25 \mathrm{~cm}$; $a^{\prime \prime}$ - sample from a depth of $\sim 30 \mathrm{~cm}$. 
there was a total reset of the accumulated energy during the fall of the meteorite, but this is highly probable because the temperature of a meteorite that falls onto the Earth must have been high, and this was passed to the surroundings in a short time span, reducing the energy in the sediment grains that surrounded the meteorite. It is well known that the high temperature (several hundred degrees Celsius), during burning of clay pots, completely whitens the heated material.

With the exception of some differences in the basic dates, results of luminescence dating correspond well with the state of current knowledge of the Morasko impact. They confirm the impact of the meteorite at about 5,000 years BP.

During luminescence measurement, the presence of the nuclide ${ }^{137} \mathrm{Cs}$ (in existence only since the mid-twentieth century when this nuclide formed after detonation of atomic bombs) was documented in a number of samples. This begs the question of whether this reflects a progressive process of cesium absorption in the meteorite crusts still lodged in sediments, or that it rather illustrates specific contamination of the crusts, during or after the cleaning of the meteorites, for instance during laboratory work. The ${ }^{137} \mathrm{Cs}$ was measured by a semi-conductor gamma spectrometer simultaneously with measurements of natural isotopes of $U$, Th and $\mathrm{K}$ in these samples. As mentioned above, for calibration reference material provided by IAEA (Soil-375) was used, and cesium was calculated based on gamma line at energy $661.7 \mathrm{keV}$.

\section{Conclusions}

The dating of the luminescence resetting time in the outer zones of small-sized meteorites (i.e., less rich fusion/melt zones which were subjected to weathering changes following impact) demonstrates that it is possible to document impact events not only by studying large specimens (i.e., our earlier data obtained for 10-164 kg meteorites), but that also analyses of small shards of extraterrestrial material may do so. The results fit well and confirm numerous earlier datings of the Morasko meteorite impact, which took place $\sim 5,000$ years BP. The TL measurements obtained of the resetting time of superficial portions of large and small objects, confirm the second author's idea about possibilities of proving impact events of stony and metallic meteorites.

In the present paper, any reference to a potential, much younger, fall of meteorites at Morasko has been omitted due to a lack of material for verification of this hypothesis.

\section{Acknowledgements}

The authors wish to express their gratitude first of all to M. Szyszko (PhD candidate, Institute of Geology UAM), who found the meteorites, to Dr G. Poręba (Silesian TechnologyUniversity) and to the scientific institutions employing them, for funding the study.

\section{References}

Adamiec, G. \& Aitken, M.J., 1998. Dose-rate conversion factors: update. Ancient TL 16, 37- 50.

Aitken, M.J., 1985. Thermoluminescence Dating. Academic Press, London, 359 pp.

Bluszcz, A., 2000. Datowanie luminescencyjne osadów czwartorzędowych - teoria, ograniczenia, problem interpretacyjne [Luminescence dating of Quaternary sediments- theory, limitations, interpretation problems]. Zeszyty Naukowe Politechniki Ślaskiej, Geochronometria 17, 86, 1-104 (in Polish).

Dworzyńska, M. \& Muszyński, A., 2010. Co mówią wyniki badań mikrometeorytów z rezerwatu „Meteoryt Morasko" [What are getting the results of Morasko Reserve micrometeorites investigations]. Acta Societatis Metheoriticae Polonorum. Rocznik Pol. Tow. Met. 3, 105-106.

Fedorowicz, S., 2006. Metodyczne aspekty luminescencyjnego oznaczania wieku osadów neoplejstoceńskich Europy Środkowej [Methodological aspects of luminescence dating of Central Europe's Neopleistocene deposits]. Wydawnictwo Uniwersytetu Gdańskiego, 156 pp. (in Polish).

Hurnik, H. (Ed.), 1976. Meteorite Morasko and the Region of its Fall. Ser. Astronomia 2, Poznań, 64 pp.

Karwowski, L., Pilski, A.S., Muszyński, A., Arnold, S., Notkin, G. \& Gurdziel, A., 2011. New finds in the Morasko Meteorite Reserve, Poland. Meteorites 1, 21-28.

Muszyński, A., Kryza, R., Karwowski, Ł., Pilski, A.S. \& Muszyńska, J. (Eds), 2012. Morasko - the largest iron meteorite shower in Central Europe. Bogucki Wydawnictwo Naukowe, Poznań, 111 pp.

Prescott, J.R. \& Hutton, J.T., 1994. Cosmic ray contributions to dose rates for luminescence and ESR dating: large depths and long-term time variations. Radiation Measurements 23, 497-500.

Science Channel, 2011. Meteorite Men, episode 302 'Morasko Poland'.

Stankowski, W.T.J., 2001. The geology and morphology of the natural reserve "Meteoryt Morasko". Planetary and Space Science 49, 749-753.

Stankowski, W.T.J., 2009. Meteoryt Morasko, osobliwość obszaru Poznania / Morasko meteorite, a curiosity of the Poznań region. Wyd. Nauk. UAM, Poznań, 94 pp.

Stankowski, W.T.J., 2011. Luminescence and Radiocarbon Dating as Tools for the Recognition of Extraterrestrial Impacts. Geochronometria 38, 50-54.

Stankowski, W.T.J. \& Bluszcz, A., 2012. Luminescence Dating as Comparative Data to Radiocarbon Age Estimation of Morasko Spherical Depressions. [In:] D. Michalska-Nawrocka (Ed.), Radiometric Dating. Intechopen, 115-126. 
Stankowski, W. \& Muszyński, A., 2008. Time of fall land some properties of the Morasko meteorite. Materials Science - Poland 26, 879-902.

Stankowski, W.T.J., Raukas, A., Bluszcz, A. \& Fedorowicz, S., 2007. Luminescencje Dating of the Morasko (Poland), Kaali, Ilumetsa, Tsoorikmae (Estonia) Meteorite Craters. Geochronometria 28, 25-29.
Wintle, A.G. \& Pruszyńska, H., 1983. TL dating of loess in Germany and Poland. PACT 6, 547-554.

Manuscript received: 7 April 2016 Revision accepted: 15 September 2016 